\title{
Mothers' Care regarding Primary School Children with Primary Headache
}

\author{
Shimaa Abd El Menem Ahmed ${ }^{1}$, Ebtisam Mohamed Abd Al-Aal ${ }^{2}$, and Huda Abdallah Moursi ${ }^{3}$
}

(1) B.Sc. Nursing (2012), (2) Professor of Community Health Nursing, Faculty of Nursing, Benha University. (3) Lecturer of Community Health Nursing, Faculty of Nursing, Benha University.

\begin{abstract}
Background: Primary headache is the most frequent neurological symptom and commonest manifestation of pain in children, between $30-40 \%$ of children report headaches at least weekly with subsequent impact at home and on school attendance and performance. The study aimed to assess mothers' knowledge and care regarding primary school children with primary headache. Research design: A descriptive research design was utilized to conduct this study. Setting: The study was conducted at Pediatric Outpatient Clinics in Benha University Hospital. Sample: A purposive sample was used, it included 236 mothers accompanied with their children Tools: A structured interviewing questionnaire was used, it was consisted of three parts: Part I; a) socio-demographic characteristics of mothers, b) personal characteristics of children, c) medical history of children. Part II; Mothers' knowledge regarding their children with primary headache. Part III; Mothers practices regarding their children with primary headache. Results: 57.2\%of studied mothers aged from 20-30 years and 46.2\% of them had basic education. $43.2 \%$ of mothers had average knowledge about primary headache, $59.7 \%$ of mothers had unsatisfactory practices about their children primary headache. Conclusion: There were statistically significant relations between mothers' total knowledge; total practice and their demographic characteristics. Also, there was significant relation between total mothers' practice and total knowledge. Recommendations: Health education program should be implemented at pediatric outpatient clinics to improve mothers' knowledge and practices regarding their children with primary headache.
\end{abstract}

Key words: Primary headache, Children, Mothers care, Knowledge \& Practices

\section{Introduction}

Primary school is important, not only for the intellectual development of children, but also for their emotional and social development. School is a major part of every child's world. Research has devoted considerable attention to the influence of bullying physical trauma on development of somatic and emotional problems, the risk of developing recurrent headache increases by $25 \%$ when school children feel their teacher is treating them unfairly. Conversely, feeling fairly treated reduces the risk by more than $40 \%$. Bullying and stress increases the risk of developing headaches in children and of taking pain medications (Better health, 2020).

Headache is the symptom of pain in the face, head, or neck. Headache is one of the most commonly experienced of all physical 


\section{Mothers' Care regarding Primary School Children with Primary Headache}

discomforts in children. Primary headache is a benign headache that is due to the headache condition itself and not due to another serious cause as brain hemorrhage. Primary headaches are the most common neurologic issue in pediatrics, affecting up to $88 \%$ of children and are one of the most common reasons that children seek medical care. Furthermore, headaches can significantly affect quality of life and cause children to miss school and extracurricular activities (Langdon \& DiSabella, 2017).

Primary headache constitute around $90 \%$ of all headache. The most common types of primary headache are migraines, tension-type headache and cluster headache. Migraine headache typically present with pulsing head pain, nausea, vomiting, phonophobia (sensitivity to sound) and photophobia (sensitivity to light). Tension-type headache present with nonpulsing pressure on both sides of the head however tension headache don't have all the symptoms of migraines, such as nausea and vomiting. In rare cases a tension headache can lead to sensitivity to light and loud noise, similar to migraines. Cluster headache are rare types of primary headache characterized by short episodes (15-180 minutes) of severe pain, usually around one eye, with autonomic symptoms (tearing, nasal congestion, red eye) which occur at the same time every day (Thomas et al., 2018).

Certain modifications may prevent many of headaches. These changes include improving sleep habits, meal schedule, increase fluid intake, stress reduction and eliminating food and environmental triggers. Give children a good breakfast so that, even if they miss lunch, they've been set up for the day. It's also helpful to put children to bed at a fixed time each evening. Nursing expertise can be used to develop improved collaborative care plans, when shared with the child, family, and primary care provider, will lead to successful continuity of long-term care (MacGrego, 2020).

Mothers should be aware when to seek help, if a child has one or more of the following, the headache occurs after a head injury, pain is severe or there are associated symptoms, such as vomiting, changes in vision or double vision, neck pain or stiffness, confusion, loss of balance or unsteadiness, and/or fever (temperature higher than $100.4^{\circ} \mathrm{F} / 38^{\circ} \mathrm{C}$ ), headache awakens the child or occurs upon waking, headaches occur more than once per month, and child has certain underlying medical conditions such as sickle cell disease, immune deficiency, bleeding problems, neurofibromatosis, or tuberous sclerosis complex (Report, 2020).

Community health nurse plays an important role that could lead to reduction of primary headache occurrence among children. Health education of mother about headache prevention and management, provide better care for their children and enhance their quality of life. The following steps may help mothers to prevent headaches or reduce the severity of headaches in children, practice healthy behaviors, behaviors that promote general good health. These lifestyle measures include getting plenty of sleep, staying physically active, eating healthy meals and snacks, drinking four to eight glasses of water daily, and avoiding caffeine. Avoid taking medications that have not been ordered by physician, avoid overuse of pain medications (Report et al., 2020). 


\section{Significance of the study}

The prevalence of primary headache in Egypt was $43.77 \%$ in the study conducted in Assuit Governorate and was $58.5 \%$ in Helwan (Ismial\& Abd Elmohsen, 2012). In Fayoum Governorate was $51.4 \%$ (El Sherbiny et al., 2015). While prevalence of headache was over 90\% which reported in the general population aged 11 years of all headache of children (International Headache Society, 2015).

\section{Aim of the study}

This study aimed to assess mothers' knowledge and care regarding primary school children with primary headache.

\section{Research questions}

1. What is the mothers' knowledge and practices regarding primary headache?

2. What is the relation between mothers' socio-demographic characteristics and their knowledge about primary headache of their primary school children?

3. What is the relation between mothers' socio-demographic characteristics and their practices regarding primary headache of their primary school children?

4. What is the relation between mothers' knowledge and practices regarding primary headache of their primary school children?

\section{Subjects and Methods}

\section{Research Design: -}

A descriptive research design was utilized to conduct this study

\section{Setting: -}

The study was conducted at the Pediatric Outpatient Clinic in Benha University Hospital because this setting is serving large sectors of children with different socio demographic characteristic.

\section{Sampling: -}

A purposive sample was used in this study, the total number of patients admitted to previous mentioned setting diagnosed with primary headache at year 2018- 2019 was 576 and the sample was taken according to this equation.

$\mathrm{n}=\frac{\mathrm{N}}{1+\mathrm{N}(\mathrm{e})^{2}}$

$\mathrm{N}=$ Total children attended 576.

$\mathrm{n}=$ sample size

$\mathrm{e}$ is coefficient factor $=0.05$

The sample included 236 children

Inclusion criteria of children:

- Diagnosed with primary headache

- Free from serious neurologic disease

(What about the mothers' sample; they are your main sample.)

\section{Tools of data collection: -}

A structured interviewing questionnaire: It was developed by researcher based on reviewing related literatures and it was written in simple Arabic language. It consisted of three parts:

\section{Part (I):}

A) Socio- demographic characteristics of the studied mothers. It included data about age, marital status, mother and father relation, qualification, income, occupational status, residence.

B) Child characteristics, it includes data about age, gender, birth order, child weight, sleeping hours, period between child and next child, child relation with teachers and friends.

C) Children medical history with primary headache, severity, site, duration, family 


\section{Mothers' Care regarding Primary School Children with Primary Headache}

history, frequency of primary headache happening in the week.

Part (II): Mother's knowledge regarding children with primary headache which included 8 closed ended question about meaning, signs and symptoms, causes, types, diagnostic methods, when mothers should go to the doctor, complications, mother's role and factors that influence on primary headache which included 7 closed ended question about sleeping hours that child need in the day, appropriate time that child spend in front of media devices, foods that reduce primary headache, foods items that increase happening of primary headache, when child eat breakfast, when child eat dinner and source of mother's knowledge about primary headache.

\section{Scoring system for knowledge:}

The mothers' knowledge was scored as 2 points for correct and complete answer while 1 point for correct and incomplete answer and zero score for incorrect and no answer.

Total scores of knowledge $=30$

The total knowledge scores was considered good if the score of the total knowledge was > $75 \%$ (> 22.5 points ), while it was considered average if it equals $50-75 \%$ (15-22.5points), and poor if it is it less than $<50 \%$ ( $<15$ points).

Part (III): Reported Mothers' practices regarding children with primary headache. It included five main practices such as: Methods of pain relief which included 5 question, put cold compress on the forehead and shoulders of the child when feel with headache, give child a safe pain reliever like paracetamol, teaching the child how to practice various relaxation technique such as slow and deep breathing, do massage for child to reduce pain. The second practice is about nutrition which included 6 questions, keep regular mealtime and don't skip any meal, feed the child healthy food and keep fast food away, ensure that the child drink sufficient amount of water and fresh juice through the day, avoid drinking tea, coffee and cola, give the child appropriate nutritional supplements according to doctor's instructions, make sure that the child eat food that reduce headache as oily fish, beans, spinach and green tea. The third practice is about sleeping which includes 6 questions: make sure that the child get enough time of sleep, make the child's bed room quiet and dark, keep the child relax in a room that tends to be cold, avoid drinking stimulants before sleeping, reduce school and home stress on my child, verify that the child is in a healthy physical and psychological condition. The fourth practice is about using of technology which includes 6 questions: reduce the child time sitting in front of the media devices and not exceeding the allowed time, make the child practice appropriate sport daily as an alternative to use of technology, keep the child participate in some household and social work to reduce technology use, organizing the child's time and taking a break between homework, training the child to extend the neck and upper part of the body when doing school homework, adding anti-glare screen for computer to protect the child. The fifth practice is about house ventilation which includes 5 questions: open all the windows of the house in the morning, allow to the sun's rays to enter the house, clean and disinfect all surfaces and floors of the house, keep my child away from smoking places, ventilate pillows, bedspreads and mattresses by 
exposing them to the air and the sun to get rid of tiny bed bugs.

\section{Scoring system}

Practice score for each answer was given as follows: 1 score for done and zero for not done.

\section{Total scores of practices $=\mathbf{2 8}$}

The total practices score was considered satisfactory if the score of the practices is $\geq 60 \%$ ( $\geq 16.8$ scores), and considered unsatisfactory if it is $<60 \%$ ( $<16.8$ score).

\section{Content validity:}

The validity of data collection tool was tested by 3 experts of Faculty Nursing Staff from the Community Health Nursing Specialists who reviewed the tool for clarity, relevance, comprehensiveness, applicability, and all recommended modifications were carried out.

\section{Reliability of tools:}

The reliability of tool was applied by the researcher for testing the internal consistency of the tool. Cronbach's Alpha for mothers knowledge was (Unacceptable value; the tool is not reliable.)

\section{Ethical consideration:}

All ethical issues were assured; Oral consent has been obtained from each mother before conducting the interview and the mothers were given a brief orientation of the purpose of the study. Mothers were also assured that all information gathered would be treated confidentially and used only for the purpose of the study. Mothers had the right to withdraw from the study at any time without giving any reasons.

\section{Pilot study:}

The pilot study was carried out on $10 \%$ (24 mothers) of the total sample of studied mothers having children with primary headache from the Pediatrics Outpatient Clinic in Benha University Hospital. The pilot study was made to assess the tool clarity, applicability and time needed to fill the questionnaire as well as to identify any possible obstacles that may hinder the data collection. No modifications were done so, these mothers were included in this study sample.

\section{Field work:}

Data were collected from the end of July 2020 to the end of September, 2020 after obtaining official permissions to conduct the study. The data was collected from mothers accompanying their children to Pediatric Outpatient Clinic at Benha University Hospital through interviewing them in the waiting area of outpatient clinic after taking their acceptance to participate in the study and explaining the aim of the study and their ethical rights. The researcher attended three days/ week from 9.00 am to $1 \mathrm{pm}$, on Sundays, Mondays and Tuesdays. The average number of interviewed mothers was between 9-10 mothers/day, each interviewed mother took about 10 to 15 minutes to complete the questionnaire depending on their response and understanding. In the presence of the researcher, the respondents filled the (The tool should be very clear and need no clarification especially you did a pilot study.)

\section{Statistical analysis:}

The collected data was analyzed, using Statistical Package for Social Sciences (SPSS) version 20Number and percentage, mean and standard deviation (SD) were used for quantitative data and Chi-square $\left(\mathbf{x}^{2}\right)$ was used for qualitative data. To determine significance 


\section{Mothers' Care regarding Primary School Children with Primary Headache}

of results $p<0.05$ is-statistically significant difference $>0.05$ is not statically significant difference and $<0.001$ highly significant difference.

\section{Results:}

Table (1): Shows that, $57.2 \%$ of the studied mothers aged from 20 to 30 years with mean age \pm SD $28.61 \pm 5.21$ and $46.2 \%$ of them had basic education. $59.3 \%$ of mothers were house wives and $56.8 \%$ of them were living in rural area while $80 \%$ of them hadn't enough income and $57.2 \%$ of studied mothers had stable relations with father.

Table (2): Reveals that $65.6 \%$ of studied children were boys and $71.3 \%$ of them aged from 9 to 10 years with mean age $\pm \mathrm{SD}$ $7.24 \pm 3.62$ Seventy five percent of the studied children sleep less than 8 hours and $40.7 \%$ of them were the first child while $45.5 \%$ were thin and $68.6 \%$ of them had troubled relationship with teachers.

Table (3): Shows that, 95.8\%, 86.9\%, 86.4\%, $80.1 \%, 79.7 \%$ of studied mothers had correct and incomplete knowledge regarding meaning, cause, mother role in protection of her child, when should a mother take her child to the doctor, signs and symptoms respectively. While, $31.8 \%, 31.4 \%, 24.6 \%$ of them had incorrect knowledge regarding types, diagnostic methods and complications respectively.

Figure (1): Illustrates that, $78.0 \%$ of the studied mothers take information about primary headache from health team and $40.7 \%$ of them had their knowledge from mass media.

Figure (2): Reveals that, $43.2 \%$ of the studied mothers had average knowledge about primary headache, $36.5 \%$ of them had poor knowledge and $20.3 \%$ of them had good knowledge about primary headache

Table (4): Shows that, there were statistically significant relations between mother's knowledge and their socio demographic characteristics.

Table (5): Shows that, there was statistically significant relation between total mothers' knowledge and total practice (p-value $<0.001$ ). 
Shimaa Abd El Menem Ahmed, Ebtisam Mohamed Abd Al-Aal, and Huda Abdallah Moursi

Table (1): Frequency distribution of studied mothers regarding their demographic characteristics $(n=236)$.

\begin{tabular}{|c|c|c|}
\hline Items & No & $\%$ \\
\hline \multicolumn{3}{|l|}{ Age } \\
\hline $20-30$ & 137 & 58.1 \\
\hline $31-40$ & 92 & 39 \\
\hline $41-50$ & 5 & 2.1 \\
\hline$>50$ & 2 & 0.8 \\
\hline \multicolumn{3}{|c|}{ Mean \pm SD $28.61 \pm 5.21$} \\
\hline \multicolumn{3}{|l|}{ Marital status } \\
\hline Married & 189 & 80.0 \\
\hline Divorce & 42 & 17.8 \\
\hline Widow & 5 & 2.2 \\
\hline \multicolumn{3}{|l|}{ Mother father relation } \\
\hline Stable & 135 & 57.2 \\
\hline Unstable & 101 & 42.8 \\
\hline \multicolumn{3}{|l|}{ Mother education } \\
\hline Illiteracy & 63 & 26.7 \\
\hline Basic Education & 109 & 46.2 \\
\hline Secondary Education & 32 & 13.6 \\
\hline Bachelor & 32 & 13.6 \\
\hline \multicolumn{3}{|l|}{ Income } \\
\hline Enough & 32 & 13.6 \\
\hline Not enough & 189 & 80.0 \\
\hline Enough and save & 15 & 6.4 \\
\hline \multicolumn{3}{|l|}{ Occupation } \\
\hline Employee & 80 & 33.9 \\
\hline House wife & 140 & 59.3 \\
\hline Free business & 16 & 6.8 \\
\hline \multicolumn{3}{|l|}{ Residence } \\
\hline Rural & 134 & 56.8 \\
\hline Urban & 102 & 43.2 \\
\hline
\end{tabular}


Table (2): Frequency distribution of studied children regarding their personal characteristics $(\mathbf{n}=236)$.

\begin{tabular}{|c|c|c|}
\hline Items & No & $\%$ \\
\hline \multicolumn{3}{|l|}{ Gender } \\
\hline Boy & 221 & 65.6 \\
\hline Girl & 15 & 34.4 \\
\hline \multicolumn{3}{|l|}{ age } \\
\hline $6-8$ & 64 & 27.1 \\
\hline $9-10$ & 168 & 71.2 \\
\hline $11-12$ & 4 & 1.7 \\
\hline \multicolumn{3}{|c|}{ Mean \pm SD 7.24 \pm 3.62} \\
\hline \multicolumn{3}{|l|}{ Weight } \\
\hline Underweight & 164 & 69.5 \\
\hline Normal & 70 & 29.7 \\
\hline Obese & 2 & 0.8 \\
\hline \multicolumn{3}{|l|}{ Ranking } \\
\hline The first child & 96 & 40.7 \\
\hline The Middle Child & 45 & 19.1 \\
\hline The youngest child & 95 & 40.2 \\
\hline \multicolumn{3}{|l|}{ Sleep hours } \\
\hline Less than 8 hours & 177 & 75.0 \\
\hline From 8 -10 hours & 9 & 3.8 \\
\hline More than 10 hours & 50 & 21.2 \\
\hline \multicolumn{3}{|c|}{ Period between child and next child } \\
\hline Year & 50 & 21.2 \\
\hline 2 year & 111 & 47.0 \\
\hline 3 year & 75 & 31.8 \\
\hline \multicolumn{3}{|l|}{ Child plays sports } \\
\hline Yes & 209 & 88.6 \\
\hline No & 27 & 11.4 \\
\hline \multicolumn{3}{|c|}{ Child relationship with friends } \\
\hline Good & 204 & 86.4 \\
\hline Troubled & 32 & 13.6 \\
\hline \multicolumn{3}{|c|}{ Child relationship with teachers } \\
\hline Good & 74 & 31.4 \\
\hline Troubled & 162 & 68.6 \\
\hline
\end{tabular}


Table (3): Frequency distribution of studied mothers regarding their knowledge about primary headache $(n=236)$.

\begin{tabular}{|c|c|c|c|c|c|c|}
\hline \multirow[t]{2}{*}{ Items } & \multicolumn{2}{|c|}{$\begin{array}{c}\text { Correct answer and } \\
\text { complete }\end{array}$} & \multicolumn{2}{|c|}{$\begin{array}{c}\text { Correct answer and } \\
\text { incomplete }\end{array}$} & \multicolumn{2}{|c|}{$\begin{array}{c}\text { Incorrect and no } \\
\text { answer }\end{array}$} \\
\hline & No & $\%$ & No & $\%$ & no & $\%$ \\
\hline Meaning & 2 & .8 & 226 & 95.8 & 8 & 3.4 \\
\hline $\begin{array}{l}\text { Signs and } \\
\text { symptoms }\end{array}$ & 4 & 1.7 & 188 & 79.7 & 44 & 18.6 \\
\hline causes & 0 & 0.0 & 205 & 86.9 & 31 & 13.1 \\
\hline Types & 4 & 1.7 & 157 & 66.5 & 75 & 31.8 \\
\hline Diagnostic methods & 6 & 2.5 & 156 & 66.1 & 74 & 31.4 \\
\hline $\begin{array}{l}\text { When should a } \\
\text { mother take her } \\
\text { child to the doctor }\end{array}$ & 0 & 0.0 & 189 & 80.1 & 47 & 19.9 \\
\hline complications & 6 & 2.5 & 172 & 72.9 & 58 & 24.6 \\
\hline $\begin{array}{l}\text { Mother role in } \\
\text { protection of her } \\
\text { child }\end{array}$ & 29 & 12.3 & 204 & 86.4 & 3 & 1.3 \\
\hline $\begin{array}{l}6 \\
4 \\
2\end{array}$ & & & & & & \\
\hline
\end{tabular}

Figure (1): Percentage of studied mothers regarding their source of information $(n=236)$.

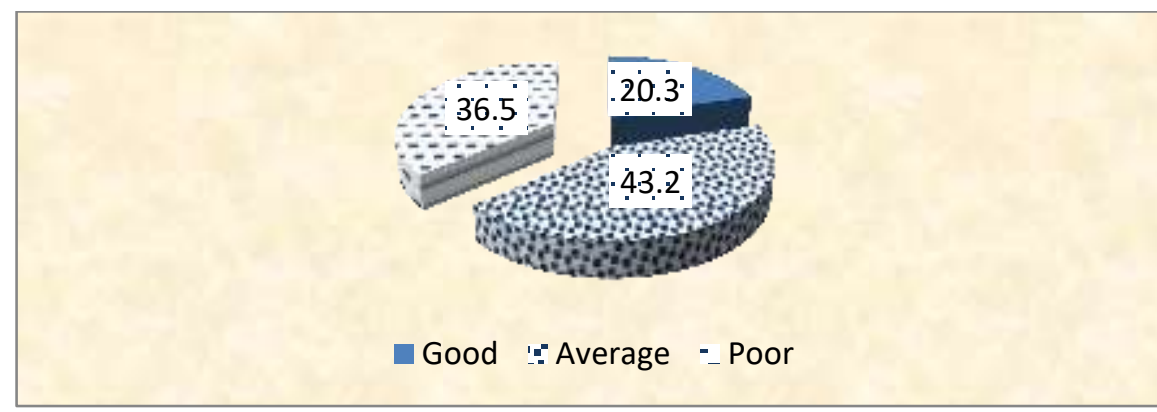

Figure (2): Frequency distribution of studied mothers regarding total knowledge about primary headache $(\mathbf{n = 2 3 6})$. 
Table (4): Relation between mothers' total knowledge score and their demographic characteristics

\begin{tabular}{|c|c|c|c|c|c|c|c|c|}
\hline \multirow[t]{2}{*}{ Demographic data } & \multicolumn{2}{|c|}{$\begin{array}{c}\text { Poor } \\
(\mathrm{n}=86)\end{array}$} & \multicolumn{2}{|c|}{$\begin{array}{l}\text { Average } \\
(\mathbf{n}=102)\end{array}$} & \multicolumn{2}{|c|}{$\begin{array}{c}\text { Good } \\
(\mathrm{n}=48)\end{array}$} & \multicolumn{2}{|r|}{ Chi-square } \\
\hline & No & $\%$ & No & $\%$ & No & $\%$ & $\mathbf{X}^{2}$ & P-value \\
\hline \multicolumn{9}{|l|}{ Mother age } \\
\hline 20 & 75 & 87.2 & 43 & 42.2 & 19 & 39.6 & \multirow{4}{*}{50.92} & \multirow{4}{*}{$0.000 * *$} \\
\hline $30-$ & 9 & 10.5 & 55 & 53.9 & 28 & 58.3 & & \\
\hline$\overline{40-}$ & 2 & 2.3 & 2 & 2 & 1 & 2.1 & & \\
\hline$>50$ & 0.0 & 0.0 & 2 & 2 & 0 & 0 & & \\
\hline \multicolumn{9}{|l|}{ Mother education } \\
\hline Illiteracy & 0 & 0.0 & 43 & 42.2 & 20 & 41.7 & \multirow{4}{*}{101.3} & \multirow{4}{*}{$0.000 * *$} \\
\hline Basic Education & 47 & 54.7 & 34 & 33.3 & 28 & 58.3 & & \\
\hline Secondary Education & 30 & 34.9 & 2 & 2.0 & 0 & 0.0 & & \\
\hline Bachelor & 9 & 10.5 & 23 & 22.5 & 0 & 0.0 & & \\
\hline \multicolumn{9}{|l|}{ Job } \\
\hline Employee & 30 & 30.0 & 77 & 20.5 & 8 & 33.0 & \multirow{3}{*}{63.29} & \multirow{3}{*}{$0.000 * *$} \\
\hline House wife & 50 & 61.0 & 25 & 69.5 & 40 & 55.0 & & \\
\hline Free business & 6 & 9 & 13 & 10 & 6 & 12.0 & & \\
\hline \multicolumn{9}{|l|}{ Residence } \\
\hline Rural & 23 & 26.7 & 74 & 72.5 & 37 & 77.1 & \multirow{2}{*}{50.01} & \multirow{2}{*}{$0.000 * *$} \\
\hline Urban & 63 & 73.3 & 28 & 27.5 & 11 & 22.9 & & \\
\hline \multicolumn{9}{|l|}{ Mother father relation } \\
\hline Stable & 47 & 54.7 & 40 & 39.2 & 48 & 100.0 & \multirow{2}{*}{$49.621^{\mathrm{a}}$} & \multirow{2}{*}{$0.000 * *$} \\
\hline Unstable & 39 & 45.3 & 62 & 60.8 & 0 & 0.0 & & \\
\hline
\end{tabular}

Table (5): Relation between mothers' total practices score and total knowledge score among studied mothers $(\mathbf{n}=\mathbf{2 3 6})$

\begin{tabular}{|c|c|c|c|c|c|c|}
\hline \multirow{3}{*}{\begin{tabular}{|l} 
Total \\
knowledge
\end{tabular}} & \multicolumn{6}{|c|}{ Total practices } \\
\hline & \multicolumn{2}{|c|}{$\begin{array}{c}\text { Unsatisfactory } \\
\quad(n=141)\end{array}$} & \multicolumn{2}{|c|}{$\begin{array}{c}\text { Satisfactory } \\
(\mathrm{n}=95)\end{array}$} & \multirow[b]{2}{*}{$X^{2}$} & \multirow[b]{2}{*}{ p-value } \\
\hline & No & $\%$ & No & $\%$ & & \\
\hline Poor $(n=86)$ & 16 & 11.3 & 70 & 73.7 & 103.37 & \multirow{3}{*}{$0.000 * *$} \\
\hline Average $(n=102)$ & 77 & 54.6 & 25 & 26.3 & & \\
\hline Good $(n=48)$ & 48 & 34.0 & 0 & 0.0 & & \\
\hline
\end{tabular}




\section{Discussion}

According to studied mothers' sociodemographic characteristics, the present study revealed that more than half of studied mothers aged from 20 to 30 years with mean age $\pm S D$ $28.61 \pm 5.21$, more than half of them were living in rural area and concerning to educational level, less than half of studied mothers had basic education. As regard to occupation more than half of studied mothers were housewives and more than half of studied mothers had not enough income. As regard to mother and father relation, more than half of studied mothers had stable relation

Concerning to studied children personal characteristics, the present study revealed that more than two thirds of the studied children were males, more than two thirds of them aged from 9 to 10 years with mean age $\pm \mathrm{SD}$ $7.24 \pm 3.62$ and were underweight. As regards to ranking, two fifths of studied children were the first child, regarding to sleep hours, three quarters of studied children sleep less than 8 hours, more than half of them play sports, the most of them had relation with friends and as regard to child relationship with teachers, more than two thirds of studied children had troubled relation with their teachers

Regarding to the gender of the studied children, the present study revealed that two thirds of them with primary headache were boys .This finding agrees with Ismail \& Abd El- Mohsen, (2015), who studied 'Headache in school age children and its possible related expected predisposing factors in Kuwiet' and found that two thirds of male students suffered from headache more than girl students. Conversely, Elshirbiny et al., (2015) when they assessed the prevalence of primary headache disorders among 2600 children in Fayoum governorate, Egypt, they reported that headaches disorders were more common in girls. This might be related to hormonal changes in both sexes.

As regards to mother's knowledge about primary headache, the present study revealed that the majority of the studied mothers had incomplete knowledge about meaning of primary headache. This finding disagrees with Brudvik et al.,(2017), who studied 'parent perception of biofeedback treatment effectiveness for pediatric migraine in Saudi Arabia' and mentioned that $54 \%$ of parents had good knowledge about their children with migraine and serve at the front lines of pediatric migraine treatment. This might be due to differences in educational level and awareness degree of the mothers.

Regarding knowledge of mother's role in protection of her child from primary headache more than two thirds of the studied mothers had incomplete knowledge about their role in protection of their children from primary headache. This finding agrees with Ochsm et al., (2012), who studied 'familial body concepts and illness attribution in primary headache in childhood in Nigeria' and revealed that $70 \%$ of parents had unclear and low knowledge about protection of their child from headaches. This might be due to dysfunctional family process, economic and social stressors that accompany an illness to the child

Regarding complications of primary headache, the present study revealed that around two thirds of the studied mothers had correct and incomplete knowledge about complications of primary headache in children. This finding 


\section{Mothers' Care regarding Primary School Children with Primary Headache}

agrees with Gibson, (2014), who studied 'determinants of impaired quality of life in children with recurrent headache in South Korea' and showed that the majority of the mothers had insufficient information about primary headache complications. This might be due to low educational level of the mothers.

Regarding the mother's knowledge about types of primary headache, the present study revealed that less than half of the studied mothers had incorrect knowledge about the types of primary headache. This finding may be due to lack of health education given to mothers about primary headaches.

Concerning the studied mother's knowledge sources about primary headache in their children the present study showed that the majority of studied mothers reported that their knowledge sources about primary headache were health team. This finding disagrees with Xiang et al., (2015), who studied 'knowledge, attitude and practices (KAP) relating to avian influenza and headache in Urban and Rural Areas of China' and found that $74.3 \%$ of studied mothers has identified mass media as the preferred source of information. This might be due to mothers' trust in physician diagnosis of their child illness. (Why not the mass media?)

Regarding to relation between socio demographic characteristics of mothers and total knowledge and practice score, the finding of the present study revealed that there were statistically significant relations. These findings are in agreement with Nayana \& Umarani (2015), who studied 'awareness of parents about an unfavorable lifestyle and headache recurrent in school children in Canada'. They reported that there was an association between knowledge, practice score, and age and educational level of the mothers. This might be due to the aging and education effect on mother's ability to acquire knowledge which affect on their practice

Concerning relation between total mothers knowledge and total practice, the results of the present study showed that there was significant relation between total mothers knowledge and total practices

This result is supported by Carlson et al., (2020), who studied 'case finding illustrating family systems interventions in a school setting to address headache, anxiety and school avoidance in England' and found a significant correlation between knowledge, attitude and practice of parents. Also, this finding agrees with Habib et al., (2016), who found that there was a positive association between the total knowledge score and total practice score. This might be due to the important role knowledge plays in changing behavior leading to change of practices.

\section{Conclusion}

About half of the studied mothers aged from 20 to 30 years and had basic education. More than half of studied children were boys and about two thirds of them aged from 9 to 10 years. There were statistically significant relation between mothers' knowledge, practice and socio-demographic characteristics. There was a statistically significant relation between total knowledge score and total practice score of mothers regarding their children with primary headache.

\section{Recommendation}

- Design a health education program for mothers attending pediatric clinics about the definition of 
headache, types, risk factors, prevention and management of primary headache.

- Integrate headache diagnosis with annual examination of students through school examination programs.

- Disseminate hazards of headache on the general health of children though mass media.

-Further studies should be done to study headache disorders in children and its effect on the quality of life.

\section{References}

Betterhealth, (2020). Growth and development - primary school children Availaple at: www.betterhealth.vic.gov.au > health.

Langdon, R. and DiSabella, M.(2017). PediatricHeadache:Anoverview.

Current Problems in Pediatric and Adolescent Health Care. 2017;47:44-65428.

Thomas, T., Bileena, K., Karanath, P., Swaroop, A. and Srinivas, R. (2018. Study on Assessment of Frequency, Intensity, Disability And Severity Associated with Primary Headaches. J App Pharm Sci, 2018; 8(02): 112118.

Straube, A., Heinen, F. and Ebinger, F. (2015). Headache in School Children: Prevelence and Risk Factors. Detsches Arzeblatt International,110(48)811-818

Macgrego, S. (2020). Headache in a National Sa: Prevalence and Comorbidity. J Child Neurol; 24:536-543: Available at: mple of American Children www.healthychildren.org.

Robert, M., Bonita, F., Joseph, W., Nina, F. and Richard E. (2020). The Global Burden of Headache: Nelson textbook of pediatrics. 21th ed. Philadelphia, Elsevier Co, PP. 26.

Lateef, T., Merikangas, K., Kalaydjian, A., Khoromi, S. and Nelson, K. (2014). Headache in a National Sample of American Children :
Prevalence and Comorbidity. J Child Neurol; 24:536-543.

Benamer, H., Donald, D. (2011). Epidemiology of Headache in Arab Countries. J Headache Pain 11:1-3 DOI 10. 1007/s10194-00173-8.

Abu-Arafeh,I., Razak, S., Sivaraman, B. and Graham, C. (2015). Prevalence of Headache and Migraine in Children and Adolescents: a Systematic Review of Population Based Studies.; 52:1088-1097.

Ismail, S. and Abed El- Mohsen, A. (2012): Headache in School Age Children and Its possible Related Expected Predisposing Factors:it available at http://www.lifesciencesite.

El-Sherbinv, N., Masoud, M., Shalabv, N. and Shehata,H. (2015). prevalence of primary Headache Disorders in Fayoum Governorate, Egypt. J Headache Rain; 16: 85. Published online 2015 Oct5. Doi: 10.1186/s10194-015-0569-6.

Gibson, J. (2014). Determinants of Impaired Quality of Life in Children with Recurrent Headache. Ohio University.

Habib, F., Al-Motairi, M. and Al-Mutairi, W. (2016). Headaches During lifespan, Global Advanced Research Journal of Medicine and Medical Science,3(5),P.97.

Carlson, M., Browning, S., Goodman, L., and Carlson, K. (2020). Case Study Illustrating Family Systems Interventions in a School Setting to Address Anxiety and School Avoidance. Journal of Family Psychotherapy, 1-19.

International Headache Society. (2015). The International Classification of Headache Disorder Cephalalgia an International Journal of Headache.

Oshinaike, O., Okubadejo, N., Ojelabi, O. and Dada, A. (2018). Primary Headache Disorders at a Tertiary Health Facility in Lagos, Nigeria: Prevalence and Consultation Patterns. BioMed Research International, 2018; 1-5. 
Alhashel, J., Alroughani, R., Shauibi, S., AlAshqar, A., AlHamdan, F., AlThufairi, H. and Ahmed, F. (2020). Impact of Primary Headache Disorder on Quality of Life Among School Students in Kuwait: Official Journal of the Italian Society for the Study of Headaches. The Journal of Headache and Pain, 21(1) doi:http://dx.doi.org/10.1186/s10194-02001124-3.

Yun, J., Lee, T. and June, H. (2018). Primary Headaches in Children and Adolescents - Experiences at a Single Headache Center in Korea. BMC Neurology, 18 doi:http://dx.doi.org/10.1186 /s12883-018-1073-9.

Xiang, N., Shi, Y., Wu, J., Zhang, S., Ye, M., Peng, Z. and Yu, H. (2015). Knowledge, attitudes and practices (KAP) relating to avian influenza in urban and rural areas of China. BMC infectious diseases, 10(1), 1-7.

El-Sherbinv, N., Masoud, M., Shalabv, N. and Shehata,H. (2015). Prevalence of primary Headache Disorders in Fayoum Governorate, Egypt. J Headache Rain; 16: 85. Published online 2015 Oct5. Doi: 10.1186/s10194-015-0569-6.

Brudvik, C., Moutte, D., Baste, V. and Morken, T. (2017). A Comparison of PainAssessment by Physicians, Parents and Children in an Outpatient Setting. Emergency Medicine Journal, 34, 138-144. https://doi.org/10.1136/emermed.

Ochs, M., Seemann, H., Franck, G., Verres, R. and Schweitzer, J. (2012). Familial body concepts and illness attributions in primary headache in childhood and adolescence. Praxis der
Kinderpsychologie und Kinderpsychiatrie, 51(3), 209-223.

Nyana, F. and Umarani, J. (2015). Planned Teaching Program Creates Awareness regarding Prevention of childhood primary headaches, International Journal of Current Research and Academic Review,2(4),Pp61-64. 


\section{تجاه الاطفال في سن المدارس الابتدائية الأين يعانون من الصداع الاولي شيماء عبدالمنعم أحمد - إبتسام تحمل عبدالعال - هلى عبدالله مرسي}

يعرف الصداع بأنه الالم الذي نشعر به في الرأس وقد يكون الالم في اي جزء من الر أس او الرقبة. الصداع الأولي هو صداع حميد ناتج عن حالة الصداع نفسها. الصداع الأولي هو المشكلة العصبية الأكثر شيوعًا في طب الأطفال ، حيث يصيب ما يصل إلى ^^٪ من الأطفال ، وهو أحد المشاكل الصحية الأكثر شيو عًا التي تتطلب حصول الأطفال على رعاية طبية. لذلك هدفت هذه الدراسة إلى تقييم رعاية الأمهات تجاه الاطفال في سن المدارس الابتدائية الذين بعانون من الصداع الاولي ، وقد اجريت هذه الدراسة في العيادات الخارجية لطب الاطفال في مستثفي جامعة بنها. وتم استخدام تصميم وصفي في هذه الدر اسة حيث تم استخدام عينة عشوائية تضم بس من الامهات نم اختيار ها بطريقة عشوائية ـ وقد خلصت النتائج بوجود علاقة ذات دلالة إحصائية بين معلومات وممارسات الأمهات الكلية تجاه اطفالهن الذين بعانون من الصداع الاولي. وقد أوصت الدراسة بضرورة تنفيذ برامج تثقيف صحي للأمهات لزيادة معلوماتهم وتحسين ممارساتهم تجاه اطفالهن الذين يعانون من الصداع الاولي. 